\title{
Expression of Concern: Human amniotic epithelial cells can differentiate into granulosa cells and restore folliculogenesis in a mouse model of chemotherapy- induced premature ovarian failure

Rocky S. Tuan ${ }^{1 *}$ and Timothy O'Brien ${ }^{2}$

\section{Expression of concern}

After publication of this article [1] it was brought to the Editors' attention that it was previously published by the OMICS Journal of Stem Cell Research \& Therapy. The authors report that they requested retraction before submission to Stem Cell Research \& Therapy but did not receive a response. The OMICS Journal of Stem Cell Research \& Therapy has now removed the article from its website without a formal retraction notice. Given that this article is no longer a duplicate publication, we have decided not to retract this version. We are issuing this Expression of Concern to alert readers should they find versions of the OMICS Journal of Stem Cell Research \& Therapy article before it was removed from that journal's website. We apologize to all affected parties.

\section{Author details}

'Center for Cellular and Molecular Engineering, Department of Orthopaedic Surgery, University of Pittsburgh School of Medicine, Pittsburgh, 15219 PA USA. ${ }^{2}$ REMEDI, CURAM, National University of Ireland Galway, Galway, Ireland.

\section{Received: 19 October 2015 Accepted: 20 October 2015}

Published online: 08 December 2015

\section{References}

1. Wang F, Wang L, Yao X, Lai D, Guo L. Human amniotic epithelial cells can differentiate into granulosa cells and restore folliculogenesis in a mouse model of chemotherapy-induced premature ovarian failure. Stem Cell Res Ther. 2013:4:124. doi:10.1186/scrt335.

\footnotetext{
*Correspondence: rst13@pitt.edu

The authors are Editors-in-Chief of Stem Cell Research \& Therapy

${ }^{1}$ Center for Cellular and Molecular Engineering, Department of Orthopaedic Surgery, University of Pittsburgh School of Medicine, Pittsburgh, 15219 PA,
} USA

(C) 2015 Tuan and O'Brien. Open Access This article is distributed under the terms of the Creative Commons Attribution 4.0

Submit your next manuscript to BioMed Central and take full advantage of:

- Convenient online submission

- Thorough peer review

- No space constraints or color figure charges

- Immediate publication on acceptance

- Inclusion in PubMed, CAS, Scopus and Google Scholar

- Research which is freely available for redistribution

Submit your manuscript at www biomedcentral.com/submit 